\title{
Music therapy reduces stress and anxiety in critically ill patients: a systematic review of randomized clinical trials
}

Michele Umbrello*1, Tiziana Sorrenti ${ }^{2}$, Giovanni Mistraletti ${ }^{1,3}$, Paolo Formenti ${ }^{1}$, Davide Chiumello ${ }^{1,4}$, Stefano Terzoni ${ }^{5}$

From the:

1 SC Anestesia e Rianimazione, Ospedale San Paolo - Polo Universitario, ASST Santi Paolo e Carlo, Milano, Italy

2 UO Cardiologia d'Urgenza, Centro Cardiologico Monzino IRCCS, Milano, Italy

3 Dipartimento di Fisiopatologia Medico-chirurgica e dei Trapianti, Università degli Studi di Milano, Milano, Italy

4 Dipartimento di Scienze della Salute, Università degli Studi di Milano, Milano, Italy

5 Corso di Laurea in Infermieristica, Università degli Studi di Milano, Milano, Italy

Corresponding author and address for reprints:

Dr. Michele Umbrello

SC Anestesia e Rianimazione

Ospedale San Paolo - Polo Universitario, ASST Santi Paolo e Carlo

Via di Rudinì, 8

20142 Milano, Italy

Email: michele.umbrello@ao-sanpaolo.it 


\begin{abstract}
Background: The underlying clinical condition and the ICU environment make critical illness is a stressful event, Although the usual management consists of sedation, non-pharmacological interventions such as music therapy have been suggested for their drug-sparing effect. Aim of the present review is to assess the current evidence on the effectiveness of music therapy in reducing stress and anxiety in critically ill, adult patients.
\end{abstract}

Methods: A systematic review of publications was undertaken using MEDLINE, CINAHL, Cochrane Library, Scopus, Web of Science, Indice Italiano di Letteratura di Scienze Infermieristiche. We included studies of critically ill patients that assessed any effect of-music therapy on stress and anxiety, which were variably assessed according to each study's definition

Results: 11 studies were included, consisting of (10 RCTs and 1 quasi-experimental design), for a total of 959 patients (range 17-373The overall quality of the studies was satisfactory; several potential sources for bias were identified. Music therapy was generally provided as a single, 30'-intervention ranging from 15 to $60^{\prime}$. Only in two studies was the intervention repeated more than once daily. The control groups were standard care, relaxation, headphones with no music or noise-cancelling headphones. Music therapy determined a significant reduction in the levels of anxiety and stress, as assessed by selfreported scales and physiologic parameters Pooled analysis was not performed due to the heterogeneity of the interventions.

Conclusions: Despite significant heterogeneity in trial designs, timing and features of the intervention, music therapy is consistently associated with a reduction in anxiety and stress of critically ill patients.

Trial registration: PROSPERO CRD42018100036, Registered on 1 august 2018

Keywords: music therapy, critical illness, intensive care unit, anxiety 


\section{Introduction}

Critically ill patients undergo a significant amount of environmental and psycho-physical stress ${ }^{1}$. Indeed, not only is their severe and debilitating underlying clinical condition stressful, but they also are subject to a wide array of stressors, related to the harsh environment in which they are cared and to the procedures to which they undergo, which all have been associated with significant discomfort ${ }^{2}$. Stress itself is a factor able to influence the body homeostasis and to activate (mal)adaptive behavioral, physiological, and cellular responses ${ }^{3}$. Anxiety is a common finding in hospitalized patients, and even more in those who are critically ill. It was suggested that up to $80 \%$ of patients in the ICU may suffer from anxiety, especially in those undergoing mechanical ventilation ${ }^{4}$. Of note, despite 20 years of advances in the treatment, critically ill patients still report as stressful events of their stay in the intensive care unit (ICU) factors such as pain, the unfamiliar environment, the loss of interaction with friends and their loved ones, the limitation in movements, the lack of sleep ${ }^{1,5-10}$.

The mainstay of therapy to manage the stress response is administration of antipsychotics, analgesics and sedatives, either by IV ${ }^{11}$ or the enteral route ${ }^{12}$, with the aim of reducing the sympathetic outflow from the nervous system. However, drugs used for this purpose are characterized by significant sideeffects, such as hemodynamic impairment, respiratory depression, ileus, delayed weaning from mechanical ventilation, prolonged immobility and ICU-acquired weakness, development of delirium and gut dysfunction, prolonged ICU stay, increased costs, development of post-ICU syndrome (cognitive dysfunction, PTSD, etc.) and long-term disability ${ }^{13-15}$.

While the administration of drugs plays an undoubtful role in the management of ICU-related stress, there are a variety of non-pharmacologic interventions and protocols, that have shown to be able to effectively prevent and treat the neuropsychologic manifestations of ICU stay, as recently reviewed ${ }^{16}$. Among such strategies, music therapy (defined as an interpersonal process in which the therapist uses music to help patients improve, or maintain health ${ }^{17}$ ) has proved effective in the modulation of the stress response, reducing the signs and symptoms of anxiety and promoting relaxation in critically ill patients ${ }^{18,19}$.

Several randomized studies have investigated the impact of music therapy in critically ill patients ${ }^{19-31}$. Despite different criteria of patient selection and a heterogeneous array of interventions, all of them suggested a reduction in anxiety and physiologic measures of stress in critically ill patients. A Cochrane Collaboration meta-analysis found that music therapy had a beneficial effect on anxiety in the ICU ${ }^{32}$. 
However, that study was performed only in mechanically ventilated patients and included also studies that investigated only the changes in hormone levels. While it is represents the main form of support of patients with respiratory failure, mechanical ventilation is reported by patients as one of the most stressful factors in the ICU ${ }^{33,34}$. However, it was shown how up to 1 in 5 critically ill patients may develop agitated delirium requiring some sort of sedation even if they are not subject to mechanical ventilation ${ }^{35,36}$, with a much higher risk for the effects of oversedation that may necessitate intubation for airway protection.

The effect of a music therapy intervention on the levels of stress and anxiety in critically ill patients who are not undergoing mechanical ventilation has not so far been summarized in review studies. The aim of the present study is to perform a systematic review of the literature on the effect of music therapy in critically ill adult patients independently of being subject to mechanical ventilation. 


\section{Materials and methods}

For the present systematic review, the PRISMA statement (preferred reporting items for systematic reviews and meta-analyses) was followed. The PICO (Patient/Intervention/Comparison/Outcome) model was used as the strategy for formulating the research question. The review protocol was registered on the International Prospective Register of Systematic Reviews (PROSPERO CRD42018100036).

\section{Study population}

We conducted a systematic review of published randomized, controlled studies of critically ill, adult patients in a medical or surgical ICU, treated with music therapy.

\section{Intervention}

All studies in which a music therapy intervention was administered to critically ill patients with the aim of reducing their levels of anxiety, stress, agitation or pain were included in the present review.

\section{Comparator}

Our comparators were the group of patients in the studies included who did not receive the intervention.

\section{Outcomes}

Randomized controlled trials available in the literature which considered the levels of stress, state anxiety, pain and agitation as outcomes were included; other physiologic outcomes, such as the levels of stress hormones, have not been considered in the current review.

\section{Study identification}

A comprehensive bibliographic search strategy was developed. The search accessed the following databases: PubMed, CINAHL, Cochrane Library, Scopus, Web of Science, ILISI - Indice Italiano di Letteratura di Scienze Infermieristiche, from inception to the cutoff date of April $30^{\text {th }}, 2018$. We restricted our search to publications in English or Italian. To supplement our search, we also manually screened the reference list of every paper to identify additional potentially eligible studies.

\section{Search strategy}


The following key-words were used, alone or combined with appropriate boolean operators, to search the different databases: music, "music therapy", "intensive care unit", "non-pharmacological interventions", anxiety, stress, pain, "vital signs", nursing, "critical care" "critically ill patients", "critical illness". A similar search was also performed using the PubMed MeSH thesaurus.

We excluded studies enrolling patients less than 18 years old or patients with known psychiatric disorders and studies investigating interventions other than music therapy (such as natural sounds) or whose outcome was the analysis of biochemical pathways (such as stress hormones).

\section{Study selection and quality assessment}

Two authors (TS, ST) independently screened the studies selected from the search strategy to identify potentially eligible studies. Studies considered to be potentially eligible then underwent full-text review. In case of disagreement the authors reviewed the article in question together until they reached a consensus. The Phisiotherapy Evidence Database (PEDro) scale ${ }^{37}$ was used to assess the methodological quality of the studies included.

\section{Data extraction and synthesis}

Two authors (TS, ST) independently extracted data from all the included studies. A specific data sheet was created to record the following information: author, year, design of the study, inclusion and exclusion criteria, population, intervention, outcomes, potential sources of bias, adverse effects of the intervention.

\section{Definition of study outcomes}

The self-reported scales of anxiety used to assess the effect of the music intervention differed among the different studies. Some authors ${ }^{20-22,27,31}$ used the short version of the Spielberger State-Trait Anxiety Inventory Scale (STAI) ${ }^{38}$ as the outcome measure for anxiety, which is composed of six out of the 20 items of the full version. Some studies ${ }^{21-23,28}$ also considered the effect of music therapy on physiologic vital parameters such as the average blood pressure, respiratory rate and heart rate. Other studies used the Faces Anxiety scale ${ }^{25}$, or the 100-mm Visual Analog Scale ${ }^{24,30}$. Agitation and sedation were assessed as the intensity and frequency of sedative drugs administered ${ }^{30}$, with the Richmond Agitation Sedation Scale (RASS) ${ }^{23}$, or with the Ramsay Score ${ }^{26}$. Pain was assessed with the numerical rating scale ${ }^{23,25}$. 


\section{Results}

A total of 511 citations were initially identified, of which 493 were subsequently excluded. The search strategy identified 18 studies, of which 17 randomized controlled clinical trials (four with a cross-over design) and one quasi-randomized trial (Figure 1) :

\section{Excluded studies}

Seven out of the 18 studies selected were excluded from the systematic review (six RCTs and one randomized crossover trial), as some assessed the effects of nature sounds (rain, wind, forest sounds) on the levels of anxiety and stress in mechanically ventilated patients ${ }^{39}$, some other investigated the possible biochemical pathways and plasma levels of stress mediator, such as the modification in plasma levels of epinephrine, norepinephrine, cortisol and corticotropins ${ }^{40}$, the levels of IL-6, growth hormone, epinephrine and dehydroepiandrosterone ${ }^{41}$ the daily excretion of free urinary cortisol ${ }^{42}$ or the plasma levels of cortisol, prolactin and adrenocorticotropic hormone ${ }^{43}$ Two studies ${ }^{23,24}$ were excluded after abstract retrieval, as they have been published in French and Chinese, respectively.

Included studies and outcomes reported

In total, 11 studies (10 RCTs and one quasi-experimental) met the inclusion criteria and were included in the systematic analysis. Study sizes ranged from as small as 17 to as large as 373 patients (median sample size 60 patients), for a total of 959 patients. Table 1 describes the main outcomes of the different studies included. Table 2 summarizes the inclusion and exclusion criteria, the study design and setting and the population enrolled. Table 3 reports the types of music therapy interventions and the main findings, as well as the possible sources of bias of each study.

Evaluation of the quality of the evidence

The quality of the evidence coming from each study was assessed with the PEDro checklist. Since none of the studies included in the present review was blinded (due to the intrinsic characteristic of the intervention), the highest possible score on the scale is eight (out of the theoretical 11 items). The summary of the quality of the assessment and the items on the PEDro scale of each study is presented in table 4. 
Effect of music therapy in state anxiety

No statistically significant baseline differences between the groups were found in any the studies included in the present review. All the studies reported a significant reduction in the level of anxiety at the end of the music intervention (Table 3). In all the studies, music therapy led to an increase in the sedation level or a reduction in the amount of sedatives administered, as well as to changes in physiologic parameters such as heart and respiratory rate and blood pressure. A lower level of pain was reported in the groups exposed to music.

\section{Adverse effects}

Music therapy is generally considered a safe intervention with no side effects. Nevertheless, none of the studies included in the current review specifically investigated the occurrence of adverse effects. Only two studies ${ }^{26,27}$ report mortality rates in patients randomized to music therapy or control, and both did not find any statistically significant difference.

Potential sources of bias

All the trials included in the current review present some sources of bias, the main being the lack of blinding, which however is unavoidable in music medicine studies that use subjective outcomes. Moreover, the majority of the studies used a single, time-limited music intervention ${ }^{19-21,27,31}$. Moreover, many studies were of limited sample size $21,22,25,26,29,31$; some are exposed to the presence of a haloeffect in the self-assessment of anxiety or stress, given the cross-over design ${ }^{21}$ or a short interval between the withdrawal of sedation and the music intervention ${ }^{28}$. In some studies, patients had a low baseline level of anxiety and discomfort, and the confounding effect of sedation and analgesia could not be ruled out ${ }^{25,29}$. Moreover, no long-term assessment of patient status has been performed in any of the studies. 


\section{Discussion}

The present systematic review suggests that music therapy is associated with significant reductions in self-reported scales of anxiety and physiological parameters used as proxy of stress in critically ill patients who are or are not treated with mechanical ventilation; the mechanism of action of the intervention was not investigated in the studies included. These results were achieved even when music therapy was provided as a short, single intervention, and are consistent in the different studies included in the analysis.

Unlike a previous meta-analysis ${ }^{32}$, we decided to include in our review also studies which included critically ill patients who were not receiving mechanical ventilation. It is known that sedation is even more problematic in these patients, given the additional risk of respiratory depression and the consequent need for securing the airway as compared to patients who are already mechanically ventilated ${ }^{35}$. We think that the current review widens the knowledge on the possible positive effects of music therapy in critically ill patients.

We chose not to perform a formal meta-analysis of the finding of the studies included, as they differed widely in terms of the features of the music intervention, the time during the course of ICU stay in which it was administered, its duration, as did the outcomes considered and the tools used to assess the effects of music therapy. Indeed, the lack of a meta-analytic approach is also the main limitation of the current review, which can impact the validity of the findings.

Despite the heterogeneity of the interventions, the results of the different studies still consistently show a significant effect of music therapy on self-reported measures of anxiety and physiologic parameters indicating stress in critically ill patients with or without mechanical ventilation. The quality of the evidence, as evaluated by the PEDro scale, is satisfactory, as all the studies are methodologically sound in terms of patient selection and administration of the intervention. However, the intrinsic characteristics of music interventions make the lack of blinding in participants, therapists and assessors unavoidable.

Potential effects of music on stress and anxiety 
Music has an intrinsic effect on the mind and feelings of persons. In consideration of its properties, it has long been considered as a therapeutic tool. Music therapy is defined as listening to music with the aim of a change in the emotional or physical state of health, and it has been used in a wide range of pathologic conditions, with special attention in the perioperative period and during ICU stay ${ }^{27,41,43-48}$.

From a technical and scientific point of view, music is defined as a complex network of organized sounds, characterized by various features, such as the rhythm, melody, harmony and time. It can be used as a therapeutic tool with the aim of an interruption in the stress response. Listening to music was shown to lead to a reduction in the level of anxiety through a complex array of effects in a neurohumoral pathway that involves the brain and autonomic system at several conscious and uncoscious levels, with modifications in the production of endorphins, cytokines and endogenous opiates $^{27,41,49-51}$.

Music therapy has proven effective in the treatment of postoperative pain $46,52,53$, in reducing the need of sedation and analgesia during surgical and endoscopic procedures ${ }^{45,54-57}$, in reducing the levels of anxiety in critically ill mechanically ventilated patients ${ }^{20-22,28}$, for the reduction of endogenous stress levels after myocardial infarction 50,58. Two meta-analyses reported positive effects of music therapy in reducing the levels of anxiety in hospitalized patients 59,60 ; however, the authors pointed out how the different methodologies of music administration and the limited power of the majority of the studies made the comparisons difficult.

Few studies have investigated the effects of music listening in the critical care setting. This intervention was shown to be associated with a reduction in self-reported levels of anxiety and reduced values of respiratory rate, heart rate and blood pressure ${ }^{20-22,48,61}$. It was shown in physiologic studies how heart and respiratory rate may synchronize with the characteristics of the music to which one listens, mainly through an activation on the autonomic system ${ }^{62}$. Although reactions to music are considered subjective, several studies suggested that cardiorespiratory variables increase with faster tempo, independent of individual preference ${ }^{63}$. It was recently shown how music emphasis and rhythmic phrases are tracked consistently by physiological variables such as skin vasomotor tone, mid-cerebral artery blood flow, R-R intervals on the EKG, and blood pressure. Autonomic responses are synchronized with music, which might therefore convey emotions through autonomic arousal during crescendos or rhythmic phrases, both in music-experienced and in naïve listeners ${ }^{64}$. 
Despite the consistent finding of reduced levels of anxiety and stress after a music therapy session, the studies differed significantly regarding the sample size and the time during the ICU stay in which the intervention was performed. Moreover, the duration of the intervention was also different among the studies, as was the possibility for the intervention to be repeated over time. In particular, the majority of studies used a single-intervention, in six of which ${ }^{19-22,27,31}$ the duration was $30^{\prime}$, in one ${ }^{29}$ it lasted $45^{\prime}$, in the study by Korhan et al. ${ }^{28}$ it was a $60^{\prime}$ intervention, in one ${ }^{25}$ the duration was $15^{\prime}$ and in another $20^{\prime}$. Only in two of the studies included was the intervention administered more than once. Dijkstra et al ${ }^{26}$ administered 30' music therapy three times in a 48h-period, while Chlan et al. ${ }^{30}$ designed a "selfinitiated music listening" study, thereby allowing patient to decide whether and when to start listening to music, for as long as the whole day; nurses and researches asked each patient to listen to the music at least twice per day, for a period of up to 30 days.

The studies included in the present review also show differences in the control group. All the studies but two have one control group; Chlan et al. ${ }^{30}$ and Han et al. ${ }^{27}$ have two different controls. Moreover, the control group was either a placebo intervention (headphones and music player with no music playing) $22,25,27,30$, or no music.

Moreover, the music therapy intervention was heterogeneous in the various studies. It was a playlist selected by the researchers and consisting of classic music ${ }^{26,28}$ or a generally-defined "relaxing" music ${ }^{29}$, or the patients had the possibility to choose among playlists of different genres ${ }^{18,20-22,25,27,31}$.

The investigations included in the current review differ in the inclusion criteria: seven studies only enrolled mechanically-ventilated patients ${ }^{20-22,26-28,30}$, of which the studies by Lee et al ${ }^{22}$, Wong et al ${ }^{21}$, Dijkstra et al ${ }^{26}$ and Korhan et al ${ }^{28}$ require a patient-triggered mode. The studies by Cooke et al ${ }^{25}$, Jaber et al Chan et al ${ }^{19}$, Su et al ${ }^{29}$ included critically ill patients independently of the presence of mechanical ventilation, while the study by Lee et al ${ }^{31}$ only included critically ill patients who were not mechanically ventilated.

\section{Clinical implications}

Despite the increasing interest of this field of research, the exact role of music therapy in the care of critically ill patients has yet to be defined. The studies included in the present review consistently 
showed how music is an inexpensive, easy to administer intervention with likely no adverse effects, which may reduce anxiety and sedation compared with usual care both in patients who are mechanically ventilated and in those who are not. However, despite these beneficial effects, this kind of non-pharmacologic intervention is still rarely observed in the daily practice. Even if we acknowledge that further studies are required, particularly with regards to the number and the duration of music sessions to be administered and the impact on longer-term outcomes such as the development of delirium and post-traumatic stress symptoms, the current evidence seems sufficient to consider the suggest the routine prescription of music therapy for patients in the intensive care unit. Administration of music therapy could be triggered by a nursing assessment of either elevated CAM ICU scores, or patient reported anxiety.

\section{Limitations}

As mentioned earlier, one of the main limitation of the current study is the lack of formal meta-analysis of the findings, which can impact the validity of the findings. We chose not to perform a forma metaanalysis of the results of the randomised trials because of their significant heterogeneity in terms of design, type and duration of intervention. The evidence arising from this review has to be considered in the context of the possible bias of the trials included in the analysis, which may preclude the generalizability of the results. All the studies but one ${ }^{30}$ are single-centre trials with limited sample size; several studies 19,21,22,24,27,29,31 have been conducted in Asia and may suffer the confounding effect of cultural aspects; only few studies ${ }^{20-22,24,25,27,30}$ allowed the patients included to choose the type of music they wanted to listen to; the use of physiologic proxies of anxiety and stress, such as heart rate or blood pressure, may be influenced by other factors (especially sedatives, vasoactive and antiarrhythmic drugs) whose administration was non-protocolized or controlled.

Despite the abovementioned limitations, the findings of reduced state anxiety and physiologic parameters of stress were consistent among the different studies, and similar to what was found when the analysis was restricted to mechanically-ventilated, critically-ill patients ${ }^{32}$ and in other categories of non-critically ill patients (namely, coronary heart disease patients ${ }^{65}$, cancer patients ${ }^{66}$, and pre-surgical patients $\left.{ }^{67}\right)$. 


\section{Conclusions}

In conclusion, this systematic review suggests how music listening may have beneficial effects on reducing state anxiety as well as limiting the physiological stress response, as assessed by heart and respiratory rate, and blood pressure in critically ill patients with and without mechanical ventilation. Since music therapy is an easy intervention to implement, we suggest to consider among the nonpharmacological strategies for anxiety and stress management to critically ill patients. Further studies are warranted to investigate the number and the duration of music sessions to be administered, as well as the impact on more clinically relevant end-points such as the long-term development of delirium and post-traumatic stress symptoms.

\section{Key messages}

- Critical illness is associated with a significant amount of stress, both because of the underlying clinical condition and for the ICU environment. Moreover, up to $80 \%$ of patients in the ICU develop anxiety.

- Even if mechanical ventilation is one of the most important stressors, also patients in the ICU who are not undergoing mechanical ventilation can develop stress and agitation.

- Although the usual management of the stress response and anxiety consists of sedation, neuroactive drugs used for this purpose are characterized by significant side-effects

- Despite significant heterogeneity in trial designs, timing and features of the intervention, we found that music therapy was consistently associated with reductions in self-reported scales of anxiety and physiological parameters used as proxy of stress in critically ill patients who are or are not treated with mechanical ventilation. 


\section{References}

1. Novaes MA, Aronovich A, Ferraz MB, Knobel E. Stressors in ICU: patients' evaluation. Intensive Care Med 1997;23:1282-5.

2. Bergbom-Engberg I, Haljamae H. Assessment of patients' experience of discomforts during respirator therapy. Crit Care Med 1989;17:1068-72.

3. Cuesta JM, Singer M. The stress response and critical illness: a review. Crit Care Med 2012;40:3283-9.

4. Castillo MI, Cooke M, Macfarlane B, Aitken LM. Factors associated with anxiety in critically ill patients: A prospective observational cohort study. Int J Nurs Stud 2016;60:225-33.

5. Novaes MA, Knobel E, Bork AM, Pavao OF, Nogueira-Martins LA, Ferraz MB. Stressors in ICU: perception of the patient, relatives and health care team. Intensive Care Med 1999;25:1421-6.

6. Mistraletti G, Umbrello M, Mariani V, Carloni E, Miori S, Taverna M, et al. Conscious sedation in critically ill patients is associated with stressors perception lower than assessed by caregivers. Minerva Anestesiol 2018.

7. Fitch M. The patient's reaction to ventilation. Can Crit Care Nurs J 1989;6:13-6.

8. Johnson MM, Sexton DL. Distress during mechanical ventilation: patients' perceptions. Crit Care Nurse 1990;10:48-57.

9. Pochard F, Lanore JJ, Bellivier F, Ferrand I, Mira JP, Belghith M, et al. Subjective psychological status of severely ill patients discharged from mechanical ventilation. Clin Intensive Care 1995;6:57-61.

10. Connelly B, Gunzerath L, Knebel A. A pilot study exploring mood state and dyspnea in mechanically ventilated patients. Heart Lung 2000;29:173-9.

11. Barr J, Fraser GL, Puntillo K, Ely EW, Gelinas C, Dasta JF, et al. Clinical practice guidelines for the management of pain, agitation, and delirium in adult patients in the intensive care unit. Crit Care Med 2013;41:263-306.

12. Mistraletti G, Umbrello M, Salini S, Cadringher P, Formenti P, Chiumello D, et al. Enteral versus intravenous approach for the sedation of critically ill patients: a randomized and controlled trial. Crit Care 2019;23:3.

13. Conti G, Mercurio G, Iacobone E, Auricchio D, Liberati Q. Sedation in the Intensive Care Unit. The basis of the problem. Minerva Anestesiol 2002;68:240-4.

14. Foster J. Complications of Sedation in Critical Illness: An Update. Crit Care Nurs Clin North Am 2016;28:227-39.

15. Cheng EY. The cost of sedating and paralyzing the critically ill patient. Crit Care Clin 1995;11:1005-19.

16. Blair GJ, Mehmood T, Rudnick M, Kuschner WG, Barr J. Nonpharmacologic and Medication Minimization Strategies for the Prevention and Treatment of ICU Delirium: A Narrative Review. J Intensive Care Med 2018:885066618771528.

17. Bruscia K. Case studies in music therapy: Gilsum NH: Barcelona Publishers; 1991.

18. Chlan L, Halm MA. Does music ease pain and anxiety in the critically ill? Am J Crit Care 2013;22:528-32.

19. Chan MF, Chung YF, Chung SW, Lee OK. Investigating the physiological responses of patients listening to music in the intensive care unit. J Clin Nurs 2009;18:1250-7.

20. Chlan L. Effectiveness of a music therapy intervention on relaxation and anxiety for patients receiving ventilatory assistance. Heart Lung 1998;27:169-76.

21. Wong HL, Lopez-Nahas V, Molassiotis A. Effects of music therapy on anxiety in ventilatordependent patients. Heart Lung 2001;30:376-87. 
22. Lee OK, Chung YF, Chan MF, Chan WM. Music and its effect on the physiological responses and anxiety levels of patients receiving mechanical ventilation: a pilot study. J Clin Nurs 2005;14:609-20.

23. Jaber S, Bahloul H, Guetin S, Chanques G, Sebbane M, Eledjam JJ. [Effects of music therapy in intensive care unit without sedation in weaning patients versus non-ventilated patients]. Ann Fr Anesth Reanim 2007;26:30-8.

24. Wu SJ, Chou FH. [The effectiveness of music therapy in reducing physiological and psychological anxiety in mechanically ventilated patients]. Hu Li Za Zhi 2008;55:35-44.

25. Cooke M, Chaboyer W, Schluter P, Foster M, Harris D, Teakle R. The effect of music on discomfort experienced by intensive care unit patients during turning: a randomized cross-over study. Int J Nurs Pract 2010;16:125-31.

26. Dijkstra BM, Gamel C, van der Bijl JJ, Bots ML, Kesecioglu J. The effects of music on physiological responses and sedation scores in sedated, mechanically ventilated patients. J Clin Nurs 2010;19:1030-9.

27. Han L, Li JP, Sit JW, Chung L, Jiao ZY, Ma WG. Effects of music intervention on physiological stress response and anxiety level of mechanically ventilated patients in China: a randomised controlled trial. J Clin Nurs 2010;19:978-87.

28. Korhan EA, Khorshid L, Uyar M. The effect of music therapy on physiological signs of anxiety in patients receiving mechanical ventilatory support. J Clin Nurs 2011;20:1026-34.

29. Su CP, Lai HL, Chang ET, Yiin LM, Perng SJ, Chen PW. A randomized controlled trial of the effects of listening to non-commercial music on quality of nocturnal sleep and relaxation indices in patients in medical intensive care unit. J Adv Nurs 2013;69:1377-89.

30. Chlan LL, Weinert CR, Heiderscheit A, Tracy MF, Skaar DJ, Guttormson JL, et al. Effects of patient-directed music intervention on anxiety and sedative exposure in critically ill patients receiving mechanical ventilatory support: a randomized clinical trial. JAMA 2013;309:2335-44. 31. Lee CH, Lee CY, Hsu MY, Lai CL, Sung YH, Lin CY, et al. Effects of Music Intervention on State Anxiety and Physiological Indices in Patients Undergoing Mechanical Ventilation in the Intensive Care Unit. Biol Res Nurs 2017;19:137-44.

32. Bradt J, Dileo C. Music interventions for mechanically ventilated patients. Cochrane Database Syst Rev 2014:CD006902.

33. Thomas LA. Clinical management of stressors perceived by patients on mechanical ventilation. AACN Clin Issues 2003;14:73-81.

34. Rotondi AJ, Chelluri L, Sirio C, Mendelsohn A, Schulz R, Belle S, et al. Patients' recollections of stressful experiences while receiving prolonged mechanical ventilation in an intensive care unit. Crit Care Med 2002;30:746-52.

35. Carrasco G, Baeza N, Cabre L, Portillo E, Gimeno G, Manzanedo D, et al. Dexmedetomidine for the Treatment of Hyperactive Delirium Refractory to Haloperidol in Nonintubated ICU Patients: A Nonrandomized Controlled Trial. Crit Care Med 2016;44:1295-306.

36. Su X, Meng ZT, Wu XH, Cui F, Li HL, Wang DX, et al. Dexmedetomidine for prevention of delirium in elderly patients after non-cardiac surgery: a randomised, double-blind, placebocontrolled trial. Lancet 2016;388:1893-902.

37. Maher CG, Sherrington C, Herbert RD, Moseley AM, Elkins M. Reliability of the PEDro scale for rating quality of randomized controlled trials. Phys Ther 2003;83:713-21.

38. Marteau TM, Bekker H. The development of a six-item short-form of the state scale of the Spielberger State-Trait Anxiety Inventory (STAI). Br J Clin Psychol 1992;31 ( Pt 3):301-6.

39. Saadatmand V, Rejeh N, Heravi-Karimooi M, Tadrisi SD, Zayeri F, Vaismoradi M, et al. Effect of nature-based sounds' intervention on agitation, anxiety, and stress in patients under mechanical ventilator support: a randomised controlled trial. Int J Nurs Stud 2013;50:895-904.

40. Chlan LL, Engeland WC, Anthony A, Guttormson J. Influence of music on the stress response in patients receiving mechanical ventilatory support: a pilot study. Am J Crit Care 2007;16:141-5. 
41. Conrad C, Niess H, Jauch KW, Bruns CJ, Hartl W, Welker L. Overture for growth hormone: requiem for interleukin-6? Crit Care Med 2007;35:2709-13.

42. Chlan LL, Engeland WC, Savik K. Does music influence stress in mechanically ventilated patients? Intensive Crit Care Nurs 2013;29:121-7.

43. Beaulieu-Boire G, Bourque S, Chagnon F, Chouinard L, Gallo-Payet N, Lesur O. Music and biological stress dampening in mechanically-ventilated patients at the intensive care unit ward-a prospective interventional randomized crossover trial. J Crit Care 2013;28:442-50.

44. Kane EON. Phonograph in Operating-Room. JAMA 1914;LXII:1829.

45. Koch ME, Kain ZN, Ayoub C, Rosenbaum SH. The sedative and analgesic sparing effect of music. Anesthesiology 1998;89:300-6.

46. McCaffrey RG, Good M. The lived experience of listening to music while recovering from surgery. J Holist Nurs 2000;18:378-90.

47. Biley F. Complementary therapy: using music in hospital settings. Nurs Stand 1992;6:37-9.

48. Almerud S, Petersson K. Music therapy--a complementary treatment for mechanically ventilated intensive care patients. Intensive Crit Care Nurs 2003;19:21-30.

49. Stefano GB, Zhu W, Cadet P, Salamon E, Mantione KJ. Music alters constitutively expressed opiate and cytokine processes in listeners. Med Sci Monit 2004;10:MS18-27.

50. White JM. Music therapy: an intervention to reduce anxiety in the myocardial infarction patient. Clin Nurse Spec 1992;6:58-63.

51. Fontaine DK. Nonpharmacologic management of patient distress during mechanical ventilation. Crit Care Clin 1994;10:695-708.

52. Good M, Anderson GC, Stanton-Hicks M, Grass JA, Makii M. Relaxation and music reduce pain after gynecologic surgery. Pain Manag Nurs 2002;3:61-70.

53. Good M, Ahn S. Korean and American music reduces pain in Korean women after gynecologic surgery. Pain Manag Nurs 2008;9:96-103.

54. Colt HG, Powers A, Shanks TG. Effect of music on state anxiety scores in patients undergoing fiberoptic bronchoscopy. Chest 1999;116:819-24.

55. Hayes A, Buffum M, Lanier E, Rodahl E, Sasso C. A music intervention to reduce anxiety prior to gastrointestinal procedures. Gastroenterol Nurs 2003;26:145-9.

56. Smolen D, Topp R, Singer L. The effect of self-selected music during colonoscopy on anxiety, heart rate, and blood pressure. Appl Nurs Res 2002;15:126-36.

57. Ayoub CM, Rizk LB, Yaacoub CI, Gaal D, Kain ZN. Music and ambient operating room noise in patients undergoing spinal anesthesia. Anesth Analg 2005;100:1316-9, table of contents.

58. White JM. Effects of relaxing music on cardiac autonomic balance and anxiety after acute myocardial infarction. Am J Crit Care 1999;8:220-30.

59. Evans D. The effectiveness of music as an intervention for hospital patients: a systematic review. J Adv Nurs 2002;37:8-18.

60. Biley FC. The effects on patient well - being of music listening as a nursing intervention: a review of the literature. Journal of Clinical Nursing 2000;9:668-77.

61. Lindgren VA, Ames NJ. Caring for patients on mechanical ventilation: what research indicates is best practice. Am J Nurs 2005;105:50-60; quiz 1.

62. Haas F, Distenfeld S, Axen K. Effects of perceived musical rhythm on respiratory pattern. J Appl Physiol (1985) 1986;61:1185-91.

63. Bernardi L, Porta C, Sleight P. Cardiovascular, cerebrovascular, and respiratory changes induced by different types of music in musicians and non-musicians: the importance of silence. Heart 2006;92:445-52.

64. Bernardi L, Porta C, Casucci G, Balsamo R, Bernardi NF, Fogari R, et al. Dynamic interactions between musical, cardiovascular, and cerebral rhythms in humans. Circulation 2009;119:3171-80. 65. Bradt J, Dileo C, Potvin N. Music for stress and anxiety reduction in coronary heart disease patients. Cochrane Database Syst Rev 2013:CD006577. 
66. Bradt J, Dileo C, Grocke D, Magill L. Music interventions for improving psychological and physical outcomes in cancer patients. Cochrane Database Syst Rev 2011:CD006911.

67. Bradt J, Dileo C, Shim M. Music interventions for preoperative anxiety. Cochrane Database Syst Rev 2013:CD006908. 


\section{Notes}

Conflict of interest: the authors declare that they have no competing interests

Authors' contributions: MU and ST conceived and designed the systematic review. TS and ST screened citation titles and abstracts to identify potentially eligible papers, TS collected the information from the articles retrieved in a datasheet. MU, PF, GM and DC wrote the paper. All authors read and approved the final manuscript

Funding: this work was performed with departmental funding only

Ethics approval and consent to participate: all the included studies were approved by the pertinent Institutional Review Board and patients gave their consent to participate 
1 Table 1 - Outcomes of the studies included in the systematic review

\begin{tabular}{|c|c|c|c|c|c|c|c|c|c|}
\hline \multicolumn{10}{|c|}{ OUTCOMES } \\
\hline \multirow[t]{2}{*}{ STUDY } & \multicolumn{4}{|c|}{ PHYSIOLOGICAL PARAMETERS } & \multirow[b]{2}{*}{ ANXIETY } & \multirow[b]{2}{*}{ PAIN } & \multirow[b]{2}{*}{ AGITATION } & \multirow[b]{2}{*}{ STRESS } & \multirow[b]{2}{*}{ OTHER OUTCOMES } \\
\hline & BP & HR & $\mathbf{R R}$ & $\mathrm{SpO}_{2}$ & & & & & \\
\hline $\begin{array}{c}\text { Chlan et al } \\
\text { (1998) }\end{array}$ & & - & - & & - & & & - & Relaxation \\
\hline $\begin{array}{l}\text { Wong et al } \\
\text { (2001) }\end{array}$ & $\bullet$ & & - & & - & & & & \\
\hline $\begin{array}{l}\text { Lee et al } \\
(2005)\end{array}$ & - & - & - & & - & & & & Relaxation, personal satisfaction \\
\hline $\begin{array}{c}\text { Chan et al } \\
\text { (2008) }\end{array}$ & - & - & - & & & & & & \\
\hline $\begin{array}{l}\text { Cooke et al } \\
(2010)\end{array}$ & & & & & - & - & & & Discomfort \\
\hline $\begin{array}{l}\text { Dijkstra et al } \\
\quad(2010)\end{array}$ & $\bullet$ & - & - & & - & & $\bullet$ & - & \\
\hline $\begin{array}{l}\text { Han et al } \\
(2010)\end{array}$ & - & - & - & - & - & & & - & Relaxation \\
\hline $\begin{array}{l}\text { Korhan et al } \\
\quad \text { (2011) }\end{array}$ & - & - & - & - & - & & & & \\
\hline $\begin{array}{l}\text { Su et al } \\
(2012)\end{array}$ & - & - & - & & & & & & Relaxation, sleep, personal satisfaction \\
\hline $\begin{array}{l}\text { Chlan et al } \\
\text { (2013) }\end{array}$ & & & & & - & & - & & \\
\hline $\begin{array}{l}\text { Lee et al } \\
(2017)\end{array}$ & - & - & & & - & & & - & Cortisol levels \\
\hline
\end{tabular}

2 BP: Blood pressure; HR: heart rate; RR: respiratory rate; $\mathrm{SpO}_{2}$ : Peripheral oxygen saturation. 
1 Table 2 - Summary of study designs

\begin{tabular}{|c|c|c|c|c|c|c|c|}
\hline STUDY & $\begin{array}{l}\text { SETTING } \\
\text { AND } \\
\text { COUNTRY }\end{array}$ & DESIGN & INCLUSION CRITERIA & $\begin{array}{c}\text { EXCLUSION } \\
\text { CRITERIA }\end{array}$ & SAMPLE SIZE & MEAN AGE & $\begin{array}{l}\text { MALE } \\
\text { SEX }\end{array}$ \\
\hline $\begin{array}{l}\text { Chlan et al } \\
\text { (1998) }\end{array}$ & $\begin{array}{c}\text { Multi-centre } \\
4 \text { urban ICU } \\
\text { USA }\end{array}$ & RCT & $\begin{array}{l}\text { Mechanically-ventilated, critically-ill patients } \\
\qquad \text { Age } \geq 18 \\
\text { Alert, mentally competent, adequate hearing, English as primary } \\
\text { language } \\
\text { Not receiving continuous intravenous sedation }\end{array}$ & $\begin{array}{l}\text { Simmetrical to } \\
\text { inclusion }\end{array}$ & $\begin{array}{c}n=54 \\
(M: 27 ; C: 27)\end{array}$ & $\begin{array}{c}57.1 \\
\text { (range: 18-89) }\end{array}$ & $41 \%$ \\
\hline $\begin{array}{l}\text { Wong et al } \\
\text { (2001) }\end{array}$ & $\begin{array}{c}\text { Single-center } \\
\text { Urban ICU } \\
\text { Hong Kong }\end{array}$ & $\begin{array}{l}\text { crossover } \\
\text { RCT }\end{array}$ & $\begin{array}{l}\text { Mechanically-ventilated, critically ill patients, undergoing } \\
\text { assisted, self-triggering ventilation } \\
\text { Age 18-85, Chinese nationality, understanding Cantonese or } \\
\text { English, able to communicate by holding up fingers } \\
\text { Alert, mentally competent, without hearing problems } \\
\text { Not receiving any continuous intravenous analgesia, } \\
\text { hemodynamically stable }\end{array}$ & $\begin{array}{l}\text { Simmetrical to } \\
\text { inclusion }\end{array}$ & $\begin{array}{c}n=20 \\
(M: 20 ; C 20)\end{array}$ & $\begin{array}{c}58.3 \\
(\mathrm{SD}: 15.5)\end{array}$ & $75 \%$ \\
\hline $\begin{array}{l}\text { Lee et al } \\
(2005)\end{array}$ & $\begin{array}{c}\text { Single-center } \\
\text { Urban ICU } \\
\text { Hong Kong }\end{array}$ & RCT & $\begin{array}{l}\text { Mechanically-ventilated, critically ill patients, undergoing } \\
\text { assisted, self-triggering ventilation } \\
\text { Alert, no psychiatric illnesses, able to hear, able to obey to } \\
\text { researcher's command }\end{array}$ & $\begin{array}{l}\text { Hemodynamically } \\
\text { unstable patients }\end{array}$ & $\begin{array}{c}n=64 \\
(M: 32 ; C: 32)\end{array}$ & $\begin{array}{c}69.4 \\
\text { (SD: } 15.2)\end{array}$ & $28 \%$ \\
\hline $\begin{array}{l}\text { Chan et al } \\
\text { (2008) }\end{array}$ & $\begin{array}{l}\text { Multi-centre } \\
3 \text { urban ICU } \\
\text { Hong Kong }\end{array}$ & $\begin{array}{c}\text { Quasi- } \\
\text { experimenta } \\
l\end{array}$ & $\begin{array}{l}\text { Critically ill patients } \\
\text { Age }>18 \text {, understanding Cantonese or Mandarin, mentally alert } \\
\text { and competent, able to communicate by body gestures, without } \\
\text { hearing defects }\end{array}$ & $\begin{array}{l}\text { Simmetrical to } \\
\text { inclusion }\end{array}$ & $\begin{array}{l}\mathrm{n}=101 \\
(\mathrm{M}: 101)\end{array}$ & Not stated & $67.3 \%$ \\
\hline $\begin{array}{c}\text { Cooke et } \\
\text { al } \\
(2010)\end{array}$ & $\begin{array}{c}\text { Multi-centre } \\
2 \text { urban ICU } \\
\text { Australia }\end{array}$ & $\begin{array}{l}\text { crossover } \\
\text { RCT }\end{array}$ & $\begin{array}{l}\text { Critically ill, postoperative patients with scheduled ICU } \\
\text { admission, both ventilated and non-ventilated; } \\
\text { Expected ICU stay >8h, able to respond to pre- and post-turning } \\
\text { discomfort and anxiety questions. }\end{array}$ & $\begin{array}{l}\text { Neurosurgery; } \\
\quad \text { Age }<18 ; \\
\text { Did not like music; } \\
\text { Impaired hearing; } \\
\text { difficulty wearing } \\
\text { earphones }\end{array}$ & $\begin{array}{c}n=17 \\
(M: 17 ; C: 17)\end{array}$ & $\begin{array}{c}72 \\
\text { (range: 19-87) }\end{array}$ & $71 \%$ \\
\hline Dijkstra & Single-center & RCT & Critically ill, mechanically-ventilated patients, undergoing self- & Simmetrical to & $\mathrm{n}=20$ & 52.2 & $60 \%$ \\
\hline
\end{tabular}




\begin{tabular}{|c|c|c|c|c|c|c|c|}
\hline $\begin{array}{c}\text { et al } \\
(2010)\end{array}$ & $\begin{array}{l}3 \text { Urban ICU } \\
\text { Netherlands }\end{array}$ & & $\begin{array}{l}\text { triggering ventilation. } \\
\text { No hearing impairment, continuous dedative infusion } \\
\text { (midazolam or propofol), Ramsay score: } 2-4\end{array}$ & inclusion & (M: 10; C:10) & (SD: 15.3) & \\
\hline $\begin{array}{l}\text { Han et al } \\
(2010)\end{array}$ & $\begin{array}{l}\text { Single-center } \\
\text { Urban ICU } \\
\text { China }\end{array}$ & RCT & $\begin{array}{l}\text { Chinese nationality, understanding Mandarin; } \\
\text { Alert, mentally competent, able to communicate by holding up } \\
\text { fingers, responsive to researchers' questions; } \\
\text { Mechanically-ventilated, undergoing synchronised intermittent } \\
\text { mandatory ventilation and/or pressure control mode; } \\
\text { Not receiving any continuous intravenous analgesia or sedative; } \\
\text { No previous experience of music intervention. }\end{array}$ & $\begin{array}{l}\text { Hearing impairment } \\
\text { or skull injury that } \\
\text { affect listening to } \\
\text { music and use of } \\
\text { headphone } \\
\text { Patients on CMV or } \\
\text { CPAP mode } \\
\text { ventilation. }\end{array}$ & $\begin{aligned} & \mathrm{n}=137 \\
&(\mathrm{M}: 44 ; \mathrm{C}: 49 ; \mathrm{P}: 44)\end{aligned}$ & $\begin{array}{l}\quad 46.2 \\
\text { (range: } 18-84 \text { ) }\end{array}$ & $43.8 \%$ \\
\hline $\begin{array}{l}\text { Korhan et } \\
\text { al } \\
\text { (2011) }\end{array}$ & $\begin{array}{l}\text { Single-center } \\
\text { Urban ICU } \\
\text { Turkey }\end{array}$ & RCT & $\begin{array}{c}\text { Turkish nationality, age 18-70; } \\
\text { Hemodynamically stable, mechanically-ventilated in pressure } \\
\text { support mode; } \\
\text { No psychiatric or neurological illnesses, not receiving inotropic } \\
\text { support, not taking any neuromuscular blocker and } \\
\text { antihypertensive drug; } \\
\text { able to hear and with Glasgow Coma Scale Point } 9 \text { or above. }\end{array}$ & $\begin{array}{l}\text { Simmetrical to } \\
\text { inclusion }\end{array}$ & $\begin{array}{c}n=60 \\
(M: 30 ; C: 30)\end{array}$ & $\begin{array}{c}45.3 \\
(\mathrm{SD} 14.7)\end{array}$ & $53.3 \%$ \\
\hline $\begin{array}{l}\text { Su et al } \\
(2012)\end{array}$ & $\begin{array}{l}\text { Single-center } \\
\text { Urban ICU } \\
\text { Taiwan }\end{array}$ & RCT & $\begin{array}{l}\text { Age>18; Acute Physiology and Chronic Health Evaluation II score } \\
\leq 25 \text {; ability to communicate in either Mandarin or Taiwanese; } \\
\text { Conscious and clear, length of ICU stay }>24 \text { hours } \\
\text { Arterial catheter inserted. }\end{array}$ & $\begin{array}{l}\text { hearing impairment; } \\
\text { physical restraint; } \\
\text { alcoholism; infectious } \\
\text { disease; } \\
\text { haemodynamic } \\
\text { instability }\end{array}$ & $\begin{array}{c}\quad \mathrm{n}=28 \\
(\mathrm{M}: 14 ; \mathrm{C}: 14)\end{array}$ & $\begin{array}{c}61.7 \\
(\mathrm{SD} 9.8)\end{array}$ & $60.7 \%$ \\
\hline $\begin{array}{l}\text { Chlan et al } \\
\text { (2013) }\end{array}$ & $\begin{array}{l}\text { Multi-centre } \\
12 \text { ICU } \\
5 \text { urban } \\
\text { hospitals } \\
\text { USA }\end{array}$ & RCT & $\begin{array}{l}\text { Mechanically-ventilated patients for acute respiratory failure; } \\
\text { Alert, participating in their daily care routines, appropriately } \\
\text { following commands, cognitively intact to participate in the } \\
\text { consent process; } \\
\text { Adequate or corrected vision and hearing. }\end{array}$ & $\begin{array}{l}\text { aggressive ventilatory } \\
\text { support, } \\
\text { vasopressors, } \\
\text { unresponsive or } \\
\text { delirious, chronic } \\
\text { ventilator support } \\
\text { prior to } \\
\text { hospitalization, } \\
\text { documented mental } \\
\text { incompetence }\end{array}$ & $\begin{array}{l}\mathrm{n}=373 \\
(\mathrm{M}: 126 ; \mathrm{P}: 122 ; \mathrm{C}: \\
\text { 125) }\end{array}$ & $\begin{array}{c}59.2 \\
(\mathrm{SD} 14.4)\end{array}$ & $48.3 \%$ \\
\hline
\end{tabular}




\begin{tabular}{|c|c|c|c|c|c|c|c|}
\hline $\begin{array}{l}\text { Lee et al } \\
(2017)\end{array}$ & $\begin{array}{c}\text { Single-center } \\
\text { Urban ICU } \\
\text { Taiwan }\end{array}$ & RCT & $\begin{array}{l}\text { Critically ill patients, admitted to the ICU for }>24 \mathrm{~h} \\
\text { Age 18-85, understanding the study purpose, able to understand } \\
\text { and communicate in Mandarin Chinese, Taiwanese (Southern } \\
\text { Min), or both; } \\
\text { Conscious and mentally clear, able to communicate using body } \\
\text { gestures, writing, or both }\end{array}$ & \begin{tabular}{|c} 
Impaired hearing, \\
skull injury \\
restricting the use of \\
headphones, \\
Use of physical \\
restraints, alcoholism, \\
infectious disease, \\
hemodynamic \\
instability, \\
Treatment with \\
continuous \\
intravenous analgesic \\
or sedatives, or \\
cortisol
\end{tabular} & $\begin{array}{c}n=85 \\
(M: 41 ; C: 44)\end{array}$ & $\begin{array}{c}59.5 \\
\text { (SD: 9.1) }\end{array}$ & $43.5 \%$ \\
\hline
\end{tabular}


1 Table 3 - Comparison of interventions and outcomes and results

\begin{tabular}{|c|c|c|c|c|}
\hline STUDY & INTERVENTION & CONTROL & OUTCOMES & RESULTS \\
\hline $\begin{array}{l}\text { Chlan et al } \\
\text { (1998) }\end{array}$ & $\begin{array}{l}30 \text { ' music tape through headphones } \\
\text { via portable cassette player } \\
\text { Choice among } 4 \text { non-lyric playlist (60- } \\
80 \text { bpm, New Age, country, religious, } \\
\text { classical) }\end{array}$ & $\begin{array}{c}30 \text { ' rest period } \\
\text { (Closing blinds, dimming lights, } \\
\text { Do-Not-Disturb sign on the } \\
\text { door) }\end{array}$ & $\begin{array}{c}\text { State Anxiety: 6-item version of the } \\
\text { Spielberger State-Trait Anxiety Inventory } \\
\text { Scale (STAI-6), at baseline and after 30' } \\
\text { Stress and agitation: heart rate and } \\
\text { respiratory rate, at baseline, every 5' } \\
\text { during assigned treatment and 5' after the } \\
\text { end }\end{array}$ & $\begin{array}{l}\text { Statistically significant difference in } \\
\text { posttest state anxiety between groups: } \\
\text { mean value } 10.16(\mathrm{M}) \text { vs. } 16.15(\mathrm{C}) \\
\qquad \mathrm{p}<0.001 \\
\text { Reduction of heart and respiratory rate } \\
\text { over time in both groups, with greater } \\
\text { reduction in Music group }\end{array}$ \\
\hline $\begin{array}{l}\text { Wong et al } \\
\text { (2001) }\end{array}$ & $\begin{array}{l}\text { 30' music tape through headphones } \\
\text { Choise among a collection of } 7 \\
\text { cassettes of relaxing, Chinese or } \\
\text { Western music } \\
\text { (Chinese folk song, music played by } \\
\text { Chinese instrument, Chinese music } \\
\text { played by Western instrument, } \\
\text { Buddhist music, Western classic, } \\
\text { Western movie music, piano music) }\end{array}$ & $\begin{array}{l}\text { 30' rest period, at least 6-hours } \\
\text { apart from music intervention } \\
\text { (drawing curtains, dimming } \\
\text { lights) }\end{array}$ & $\begin{array}{l}\text { Anxiety: 6-item version of the Spielberger } \\
\text { State-Trait Anxiety Inventory Scale (STAI- } \\
\text { 6), at baseline and after 30' } \\
\text { Stress and agitation: mean blood pressure } \\
\text { and respiratory rate, at baseline, every 5' } \\
\text { during assigned treatment }\end{array}$ & $\begin{array}{l}\text { Subjects in both conditions had reduced } \\
\text { state anxiety scores over time; music } \\
\text { therapy was more effective than a rest } \\
\text { period in reducing state anxiety (C } \\
49.67 \pm 4.82 \text { vs. M } 38.67 \pm 5.23, \mathrm{p}<0.01 \text { ) } \\
\text { Reduction of blood pressure and } \\
\text { respiratory rate over time in both groups, } \\
\text { with greater reduction in Music group }\end{array}$ \\
\hline $\begin{array}{l}\text { Lee et al } \\
(2005)\end{array}$ & $\begin{array}{l}\text { 30' music tape through CD-player and } \\
\text { headphones } \\
\text { Music selected by the patient from } \\
\text { researcher collection (Chinese } \\
\text { classical music, religious music, } \\
\text { Western classical music, music of } \\
\text { natural sounds). }\end{array}$ & $\begin{array}{l}\text { 30' placebo, through CD-player } \\
\text { and headphones but without CD } \\
\text { playing. }\end{array}$ & $\begin{array}{l}\text { Anxiety: 6-item version of the Spielberger } \\
\text { State-Trait Anxiety Inventory Scale (STAI- } \\
\text { 6), at baseline and after 30'; Behavioural } \\
\text { checklist developed by the researcher } \\
\text { recorded during intervention } \\
\text { Stress and agitation: heart rate, systolic } \\
\text { and diastolic blood pressure and } \\
\text { respiratory rate, at baseline, and after the } \\
\text { intervention } \\
\text { Self-reported satisfaction after the } \\
\text { intervention }\end{array}$ & $\begin{array}{l}\text { Subjects in the music group had reduced } \\
\text { state anxiety scores over time: } 15.4 \pm 4.6 \text { vs. } \\
13.8 \pm 2.8, \mathrm{p}=0.048 \text {; state anxiety in the } \\
\text { control group was similar to baseline value } \\
\text { Respiratory rate, heart rate, systolic and } \\
\text { diastolic blood pressure were all } \\
\text { significantly lower than baseline in the } \\
\text { music group, while only diastolic blood } \\
\text { pressure was reduced after the } \\
\text { intervention in the control group. }\end{array}$ \\
\hline $\begin{array}{l}\text { Chan et al } \\
\text { (2008) }\end{array}$ & $\begin{array}{l}\text { 30' of music through headphones and } \\
\text { mp3 or CD player } \\
\text { Music chosen based on previous } \\
\text { studies: relaxing music defined } \\
\text { primarily as being low-pitched, having } \\
\text { a simple and direct musical rhythm } \\
\text { and having a tempo of approximately }\end{array}$ & No control group & $\begin{array}{c}\text { Demographic variables: age, gender, } \\
\text { religion, education level, previous or } \\
\text { current use of relaxation techniques. } \\
\text { Physiological parameters: Systolic and } \\
\begin{array}{c}\text { diastolic blood pressure, heart and } \\
\text { respiratory rate }\end{array}\end{array}$ & $\begin{array}{l}\text { A higher therapeutic effect of music } \\
\text { (significant reduction in heart and } \\
\text { respiratory rate and blood pressure) was } \\
\text { found in female patients, patients older } \\
\text { than } 65 \text { years, and mechanically-ventilated } \\
\text { patients. } \\
\text { A lower effect was found in males and in }\end{array}$ \\
\hline
\end{tabular}




\begin{tabular}{|c|c|c|c|c|}
\hline & $\begin{array}{l}60-80 \text { bpm. } \\
\text { Music used: Chinese classical music, } \\
\text { religious music and Western classical } \\
\text { music and Jazz }\end{array}$ & & Data recorded at baseline, $15^{\prime}$ and $30^{\prime}$ & those with higher levels of education. \\
\hline $\begin{array}{l}\text { Cooke et al } \\
\text { (2010) }\end{array}$ & $\begin{array}{l}60 \text { ' of music through CD player and } \\
\text { headphones before and during the } \\
\text { turning procedure. } \\
\text { Music chosen preoperatively from a } \\
\text { selection of classical, jazz, country and } \\
\text { western, new age, easy-listening or } \\
\text { 'other' (mostly by contemporary } \\
\text { artists) music provided by the } \\
\text { researchers. }\end{array}$ & $\begin{array}{l}15^{\prime} \text { of headphones and CD player } \\
\text { with no music playing. }\end{array}$ & $\begin{array}{l}\text { Discomfort: measured by Numerical } \\
\text { Rating Scale (NRS) } \\
\text { Anxiety: measured through Faces Anxiety } \\
\text { Scale (FAS) } \\
\text { Both measured } 15^{\prime} \text { before and } 15^{\prime} \text { after } \\
\text { intervention }\end{array}$ & $\begin{array}{l}\text { No significant reduction of discomfort (M: } \\
2.7(1.7 ; 3.7) \text { vs. } 3.6(2.0 ; 5.2) \text { and } \mathrm{C}: 3.4 \\
(2.2 ; 4.6) \text { vs. } 2.8(1.3 ; 4.2) ; \text { both } \mathrm{p}>0.05) \text { or } \\
\text { anxiety in both groups. }\end{array}$ \\
\hline $\begin{array}{l}\text { Dijkstra } \\
\text { et al } \\
(2010)\end{array}$ & $\begin{array}{l}3 \text { sessions spread over } 2 \text { days, each } \\
\text { lasting } 30 \text { ' of music through mp3 } \\
\text { player and headphones. } \\
\text { between } 10 \text { am and noon and } \\
\text { between } 8 \text { and } 10 \mathrm{pm} \\
\text { Classical and easy-listening music } \\
\text { chosen by patient or caregiver. }\end{array}$ & $\begin{array}{l}\text { Control: } 3 \text { sessions spread over } \\
2 \text { days, each lasting 30' of rest } \\
\text { period }\end{array}$ & $\begin{array}{l}\text { Stress: systolic, diastolic and mean blood } \\
\text { pressure, heart and respiratory rate, } \\
\text { assessed at baseline and } 5^{\prime}, 10^{\prime}, 20^{\prime}, 30^{\prime} \text { and } \\
60^{\prime} \text { from the beginning of the } \\
\text { intervention. } \\
\text { Sedation: Ramsay score, at baseline and } \\
\text { at the end of the intervention. }\end{array}$ & $\begin{array}{l}\text { No differences in blood pressure, heart or } \\
\text { respiratory rate between groups. } \\
\text { Significantly higher level of sedation in } \\
\text { music group (Ramsay M } 3.8 \pm 0.8 \text { vs. } 4.3 \pm 0.7 \text {; } \\
\text { C } 4.6 \pm 0.9 \text { vs. } 4.0 \pm 1.4 ; p=0.015 \text { ) }\end{array}$ \\
\hline $\begin{array}{l}\text { Han et al } \\
\text { (2010) }\end{array}$ & $\begin{array}{c}\text { 30' of music through headphones and } \\
\text { mp3 player through foam-lined } \\
\text { headphones. } \\
\text { Music chosen by patients from the } \\
\text { investigator's collection. } 4 \text { categories } \\
\text { of relaxing music, including Western } \\
\text { classical music, Western light music, } \\
\text { Chinese traditional music and Chinese } \\
\text { folk. }\end{array}$ & $\begin{array}{l}\text { Placebo: patients wearing foam- } \\
\text { lined headphone and resting } \\
\text { with their eyes closed for } 30^{\prime}, \text { no } \\
\text { music playing. } \\
\text { Control: patients resting with } \\
\text { their eyes closed for } 30^{\prime} \text {, with } \\
\text { neither headphone nor music. }\end{array}$ & $\begin{array}{l}\text { Anxiety measured by the Chinese version } \\
\text { of the Spielberger State-Trait Anxiety } \\
\text { inventory Scale (C-STAI), at baseline and } \\
\text { at the end of intervention. } \\
\text { Stress and relaxation: heart and } \\
\text { respiratory rate, blood pressure, arterial } \\
\text { oxygen saturation, at baseline and at 5' } \\
\text { intervals. }\end{array}$ & $\begin{array}{l}\text { Significant differences in heart and } \\
\text { respiratory rate, systolic and diastolic blood } \\
\text { pressure, and C-STAI, but not in SaO2 } \\
\text { among the three groups } \\
\text { Greater mean differences in music group } \\
\text { (Delta pre-post M } 10.7 \pm 6.82 \text { vs. P } 3.34 \pm 5.37 \\
\text { vs. C } 0.76 \pm 4.97 ; \text { p }<0.001 \text { ). } \\
\text { Significant reduction in stress response } \\
\text { (heart respiratory rate) over time in music } \\
\text { group while a significant increase in heart } \\
\text { rate and respiratory rate over time in } \\
\text { control, no significant change over time in } \\
\text { headphone. }\end{array}$ \\
\hline $\begin{array}{l}\text { Korhan et } \\
\text { al } \\
\text { (2011) }\end{array}$ & $\begin{array}{l}60 \text { ' of music through mp3 player and } \\
\text { disposable headphones } \\
\text { Classic music ( } 60-66 \mathrm{bpm}) \text {, at least } 30^{\prime} \\
\text { after stopping of intravenous } \\
\text { sedation. }\end{array}$ & 60 of rest, standard care & $\begin{array}{l}\text { Anxiety: physiological measurements as } \\
\text { systolic and diastolic blood pressure, } \\
\text { pulse rate, respiratory rate and oxygen } \\
\text { saturation, at baseline, } 30^{\prime}, 60^{\prime} \text { and } 90^{\prime} .\end{array}$ & $\begin{array}{l}\text { M: significantly lower respiratory rates, and } \\
\text { systolic and diastolic blood pressure, than } \\
\text { C; the decrease improved progressively at } \\
30^{\prime}, 60^{\prime} \text { and 90', indicating a cumulative } \\
\text { dose effect; } \\
\text { No differences in heart rate and oxygen }\end{array}$ \\
\hline
\end{tabular}




\begin{tabular}{|c|c|c|c|c|}
\hline & & & & saturation. \\
\hline $\begin{array}{l}\text { Su et al } \\
(2012)\end{array}$ & $\begin{array}{l}45^{\prime} \text { of music through CD player and } \\
\text { headphones during nocturnal sleep } \\
\text { time. } \\
\text { Four pieces of sedating piano music } \\
\text { composed by two of the authors; } \\
\text { volume: } 30-40 \mathrm{~dB}, 60-80 \mathrm{bpm}) .\end{array}$ & Control: no music listening & $\begin{array}{l}\text { Stress and relaxation: heart and } \\
\text { respiratory rate, mean arterial pressure, } \\
\text { at baseline and at 5' intervals } \\
\text { Sleep quality: polysomnography and } \\
\text { validated questionnaires (Verran and } \\
\text { Synder-Halpern Sleep Scale) }\end{array}$ & $\begin{array}{c}\text { Improved polysomnography quality of } 2 \\
\text { sleep in music group (shorter N2 and } 3 \\
\text { longer N3 sleep), and improved self- } \\
\text { reported sleep quality, } \\
\text { Music group had significantly lower heart } \\
\text { rates than control }\end{array}$ \\
\hline $\begin{array}{l}\text { Chlan et al } \\
\text { (2013) }\end{array}$ & $\begin{array}{l}\text { Standard CD/MP3 player with } \\
\text { comfortable, noise-cancelling } \\
\text { headphones with a starter set of } 6 \text { CDs } \\
\text { (relaxing music played on piano, harp, } \\
\text { guitar, and Native American flute) } \\
\text { Within 24h, the music therapist } \\
\text { completed a music preference } \\
\text { assessment on each patient using a } \\
\text { specific tool } \\
\text { Music offered at least twice per day } \\
\text { (when feeling anxious and/or to } \\
\text { provide relaxation), with self- } \\
\text { initiation encouraged }\end{array}$ & $\begin{array}{c}\text { Placebo: "self-initiated" use of } \\
\text { noise-cancelling headphones } \\
\text { whenever they wanted to block } \\
\text { out ICU noise or have some quiet } \\
\text { time. } \\
\text { Control: normal care }\end{array}$ & $\begin{array}{l}\text { Anxiety: } 100 \mathrm{~mm} \text { visual analog scale (VAS- } \\
\text { A) } \\
\text { Sedation: Sedation intensity and sedation } \\
\text { frequency scores }\end{array}$ & 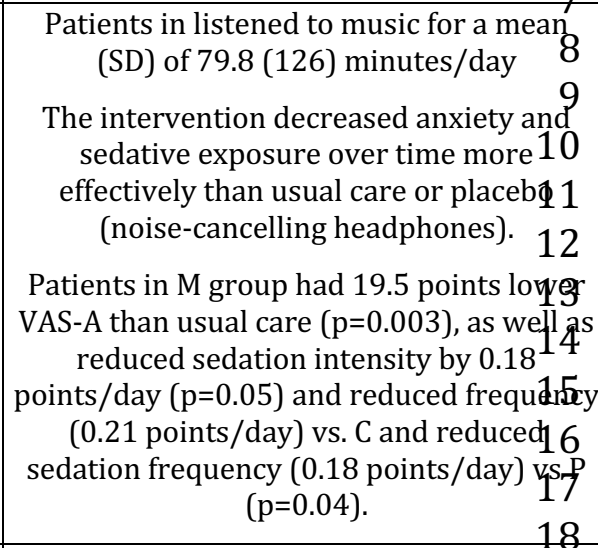 \\
\hline $\begin{array}{l}\text { Lee et al } \\
\text { (2017) }\end{array}$ & $\begin{array}{l}30 \text { ' music listening through mp3 } \\
\text { player and headphones between } 4- \\
4.30 \text { pm } \\
\text { Music chosen by patients among } \\
\text { researchers catalogue of slow-beat } \\
(60-80 \text { bpm), relaxing music: Western } \\
\text { classical music, Chinese classical } \\
\text { music, music of natural sounds, or } \\
\text { religious music }\end{array}$ & $\begin{array}{l}\text { 30' of rest between } 4-4.30 \mathrm{pm} \text {; } \\
\text { headphones with no music } \\
\text { playing }\end{array}$ & $\begin{array}{l}\text { Anxiety: measured as serum cortisol } \\
\text { levels (objective indicator) and as the } \\
\text { Chinese version of the Spielberger State- } \\
\text { Trait Anxiety inventory Scale (C-STAI) } \\
\text { and the Visual-Analogue Scale (VAS-A) } \\
\text { scores (subjective indicators). } \\
\text { Stress: heart rate and blood pressure. }\end{array}$ & $\begin{array}{c}\text { Significant better values for all postte } 19 \\
\text { measures and for pre-post differences } 20 \text { r } \\
\text { music as compared to control (C-STALM } \\
57.2 \pm 7.64 \text { vs. } 51.5 \pm 5.1 \text {, C } 57.2 \pm 5.8 \text { vs. } \\
56.2 \pm 5.6, \text { p }<0.001 \text {; VAS-A STAI M } 57.2 \pm 2 \\
\text { vs. } 49.6 \pm 8.1, \text { C } 58.0 \pm 8.2 \text { vs. } 56.1 \pm 9.223 \\
\text { p<0.001) except for diastolic blood } 24 \\
\text { pressure }\end{array}$ \\
\hline
\end{tabular}

BIS: bispectral index; RASS: Richmond agitation-sedation scale; M: music group; C: control group; P: placebo group 
1 Table 4 - Quality assessment of the included trials using the PEDRO scale

\begin{tabular}{|c|c|c|c|c|c|c|c|c|c|c|c|c|}
\hline Study & 1 & 2 & 3 & 4 & 5 & 6 & 7 & 8 & 9 & 10 & 11 & Total \\
\hline $\begin{array}{l}\text { Chlan et al } \\
\text { (1998) }\end{array}$ & $\checkmark$ & $\checkmark$ & $\checkmark$ & $\checkmark$ & & & & $\checkmark$ & $\checkmark$ & $\checkmark$ & $\checkmark$ & 8 \\
\hline $\begin{array}{l}\text { Wong et al } \\
(2001)\end{array}$ & $\checkmark$ & $\checkmark$ & $\checkmark$ & $\checkmark$ & & & & $\checkmark$ & $\checkmark$ & $\checkmark$ & $\checkmark$ & 8 \\
\hline $\begin{array}{l}\text { Lee et al } \\
(2005)\end{array}$ & $\checkmark$ & $\checkmark$ & $\checkmark$ & $\checkmark$ & & & & $\checkmark$ & $\checkmark$ & $\checkmark$ & $\checkmark$ & 8 \\
\hline $\begin{array}{l}\text { Chan et al } \\
(2008)\end{array}$ & $\checkmark$ & & $\checkmark$ & & & & & $\checkmark$ & $\checkmark$ & $\checkmark$ & $\checkmark$ & 6 \\
\hline $\begin{array}{l}\text { Cooke et al } \\
\text { (2010) }\end{array}$ & $\checkmark$ & $\checkmark$ & $\checkmark$ & $\checkmark$ & & & & & $\checkmark$ & $\checkmark$ & $\checkmark$ & 7 \\
\hline $\begin{array}{c}\text { Dijkstra et al } \\
\text { (2010) }\end{array}$ & $\checkmark$ & $\checkmark$ & $\checkmark$ & $\checkmark$ & & & & & & $\checkmark$ & $\checkmark$ & 6 \\
\hline $\begin{array}{l}\text { Han et al } \\
\text { (2010) }\end{array}$ & $\checkmark$ & $\checkmark$ & $\checkmark$ & $\checkmark$ & & & & $\checkmark$ & $\checkmark$ & $\checkmark$ & $\checkmark$ & 8 \\
\hline $\begin{array}{l}\text { Korhan et al } \\
\text { (2011) }\end{array}$ & $\checkmark$ & $\checkmark$ & $\checkmark$ & $\checkmark$ & & & & $\checkmark$ & $\checkmark$ & $\checkmark$ & $\checkmark$ & 8 \\
\hline $\begin{array}{l}\text { Su et al } \\
\text { (2012) }\end{array}$ & $\checkmark$ & $\checkmark$ & $\checkmark$ & $\checkmark$ & & & & $\checkmark$ & $\checkmark$ & $\checkmark$ & $\checkmark$ & 8 \\
\hline $\begin{array}{l}\text { Chlan et al } \\
\text { (2013) }\end{array}$ & $\checkmark$ & $\checkmark$ & $\checkmark$ & & & & & $\checkmark$ & $\checkmark$ & $\checkmark$ & $\checkmark$ & 7 \\
\hline $\begin{array}{c}\text { Lee et al } \\
(2017)\end{array}$ & $\checkmark$ & $\checkmark$ & $\checkmark$ & $\checkmark$ & & & & $\checkmark$ & $\checkmark$ & $\checkmark$ & $\checkmark$ & 8 \\
\hline
\end{tabular}

2 1: eligibility criteria and source of participants; 2: random allocation; 3: concealed allocation; 4: baseline comparability; 5: blinded

3 participants; 6: blinded therapists; 7: blind assessors; 8: adequate follow-up; 9: intention-to-treat analysis; 10: between-group comparisons;

4 11: point estimates and variability. 


\section{Figure legends}

2

3 Figure 1 Flow chart of the study selection process. CINAHL: Cumulative Index to Nursing and Allied 4 Health Literature; ILISI: Indice della Letteratura Italiana di Scienze Infermieristiche. 